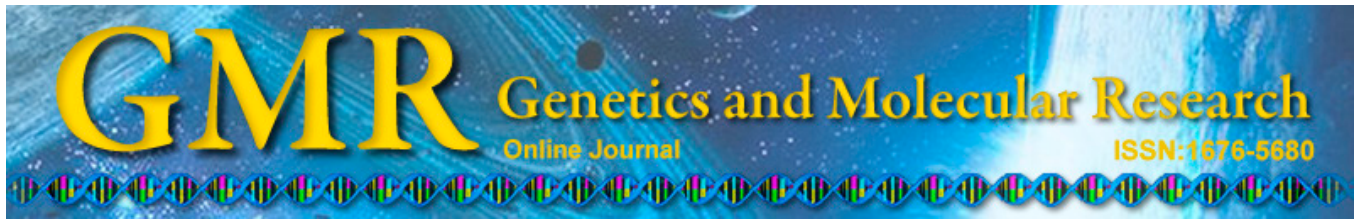

\title{
Phenotyping of Passiflora edulis, $P$. setacea, and their hybrids by a multivariate approach
}

\author{
E.A. Santos ${ }^{1}$, A.P. Viana ${ }^{1}$, J.C.O. Freitas ${ }^{1}$, M.M. Souza ${ }^{2}$, C.L. Paiva, \\ D.L. Rodrigues ${ }^{1}$ and R.F. Tavares ${ }^{1}$ \\ ${ }^{1}$ Laboratório de Melhoramento Genético Vegetal, \\ Centro de Ciências e Tecnologias Agropecuárias, \\ Universidade Estadual do Norte Fluminense Darcy Ribeiro, \\ Campos dos Goytacazes, RJ, Brasil \\ ${ }^{2}$ Departamento de Ciências Biológicas, \\ Universidade Estadual de Santa Cruz, Ilhéus, BA, Brasil \\ Corresponding author: E.A. Santos \\ E-mail: eileenazevedo@yahoo.com.br
}

Genet. Mol. Res. 13 (4): 9828-9845 (2014)

Received January 21, 2014

Accepted May 11, 2014

Published November 27, 2014

DOI http://dx.doi.org/10.4238/2014.November.27.10

\begin{abstract}
Morphological characterization is the most accessible and used method to quantify the genetic diversity of the available germplasm. The multivariate statistical method is highly important for this purpose. This study aimed to characterize parents and hybrids of Passiflora according to morphoagronomic descriptors and estimate the genetic divergence between them based on the joint analysis of qualitative and quantitative variables using the Ward-modified location model (MLM) procedure. One hundred and thirty-eight individuals were assessed (10 P. edulis, $10 \mathrm{P}$. setacea, and 118 interspecific hybrids) using 23 quantitative and 12 qualitative descriptors. The values for the quantitative descriptors were measured and subjected to multivariate statistics using the Ward-MLM strategy. Large genetic variability was detected by the morphoagronomic data in the 138 genotypes that were evaluated, and the hybrids presented higher variability than the parents. Pseudo-F and pseudo- $\mathrm{t}^{2}$ criteria showed that the optimal number of groups was three.
\end{abstract}


Group I was composed of 118 hybrid genotypes; group II was composed of the $10 P$. setacea genotypes, and group III was composed of the $10 P$. edulis genotypes. The longest distance was found between groups II and III (474.96). The shortest distance was detected between groups I and II (198.78), which indicates that the segregating population is genetically closer to $P$. setacea than to $P$. edulis. The Ward-MLM procedure is a useful tool to detect genetic diversity and group accessions using both qualitative and quantitative variables.

Key words: Ward-modified location model (MLM) method; Interspecific hybrid; Joint analysis; Morphoagronomic characterization; Genetic divergence

\section{INTRODUCTION}

Passion fruit (Passiflora edulis Sims) is a tropical fruit whose cultivation has rapidly evolved in Brazil over the last 30 years (Bernacci et al., 2008; Meletti, 2011). Brazil is the largest passion fruit producer, producing 923.035 ton/ha (IBGE, 2011). Despite its economic relevance, passion fruit production is still limited by diseases in orchards, which lead to losses in fruit quality and production. Passion fruit woodiness virus is caused by Cowpea aphidborne mosaic virus (CABMV) and is one of the diseases that affects passion fruit crops. It has impaired production in all regions where this fruit is cultivated (Nascimento et al., 2006).

Because of the low genetic variability among the sour passion fruit cultivars that are available for developing resistance to fruit woodiness virus, selected crosses between the cultivated species and resistant wild relatives are used in some strategies that were adopted to control the disease. Among the wild species that were indicated as potential sources of resistance to diseases affecting passion fruit, Passiflora setacea DC deserves special attention because it is resistant to CABMV (Junqueira et al., 2006; Bellon et al., 2009). The characterization of a segregating population by means of morphoagronomic descriptors is particularly important for breeders because of the wide variability that is available in the population that remains little known or exploited. Furthermore, it also allows the identification of superior genotypes for advanced generations in the breeding program (Primot et al., 2005).

The use of multivariate statistics is very significant, especially when a large number of descriptors are used to quantify the dissimilarity between individuals. Multivariate procedures unify information from a set of traits and provide robust studies related to genetic divergence, which is relevant to understand the genetic variability of populations (Gonçalves et al., 2008).

There are several available methods to estimate genetic diversity. However, caution is necessary in the selection of a method because it may considerably affect the estimates (Mohammadi and Prasanna, 2003). Determining the method to estimate similarity (and its complement, dissimilarity) depends on the objectives proposed in the research, the characteristics of the variables, and the inherent properties of the distances and coefficients. In general, statistical classification methods only consider continuous or discrete data separately (Padilla et al., 2007). However, new methodologies allow the simultaneous analysis of quantitative and qualitative data.

The Ward-modified location model (MLM) procedure, which was proposed by Franco et al. (1998), is a multivariate method that is an excellent strategy for quantifying variability using quantitative and qualitative variables simultaneously. This strategy involves two stages: 
in the first stage, the groups are defined by the Ward clustering method (Ward Junior, 1963) using the Gower dissimilarity matrix (Gower, 1971); in the second stage, the mean quantitative variable vector for each subpopulation is estimated by the MLM procedure, regardless of the values of the qualitative variable. This method has been widely employed in the past five years, especially in studies on genetic diversity aiming to support plant-breeding programs. These procedures have been used by Gonçalves et al. (2009) in Solanum lycopersicum; Barbé et al. (2010) in Phaseolus vulgaris; and Sudré et al. (2010) in Capsicum spp. There are also reports of using this procedure to study banana (Pestana et al., 2011; Pereira et al., 2012) and guava (Campos et al., 2013).

Therefore, this study aimed to characterize parents and hybrids of Passiflora based on morphoagronomic descriptors and to estimate the genetic divergence between them based on the joint analysis of qualitative and quantitative variables using the Ward-MLM procedure.

\section{MATERIAL AND METHODS}

\section{Germplasm}

We evaluated 138 individuals from the passion fruit breeding program of the Universidade Estadual do Norte Fluminense Darcy Ribeiro (UENF) that included 10 genotypes of $P$. edulis, 10 genotypes of $P$. setacea, and 118 interspecific hybrids that were obtained from crosses between these species. The genotypes of $P$. setacea were from the Active Germplasm Bank (BAG-Passifloras) of the Universidade Estadual de Santa Cruz (UESC), Ilheus, Bahia; the genotypes of passion fruit were obtained from the recurrent selection program of the UENF. Hybridizations were performed using $P$. edulis as the female and male parents to obtain the $\mathrm{S}_{0}$ progenies (Table 1).

$\begin{aligned} & \text { Table 1. Genotypes of Passiflora edulis }(P e) \text { and } P \text {. setacea }(P s) \text { used in interspecific crosses to obtain the full- } \\
& \text { sib progenies of Passiflora spp. }\end{aligned}$
\begin{tabular}{lll}
\hline Parents/Crosses & Progenies & Genotypes \\
\hline$P e 139(40) \times P s 367$ & UENFH-1 & $1,2,3,4,7,8,9,10,11,12,14,16,19,20,22$ \\
$P e 139(38) \times P s 367$ & UENFH-2 & $2,3,4,7,10,11,12,13,14,15,16,17,18,20,23$ \\
$P e 139(29) \times P s 367$ & UENFH-3 & $2,4,6,7,8,9,10,11,13$ \\
$P e 89(11) \times P s(365)$ & UENFH-4 & $2,3,5,9,13,17,21$ \\
$P s 367 \times P e 139(40)$ & UENFH-5 & $1,2,3,4,5,7,8,9,10,12,13,14,15,16,17,18,19,20,21,22,23$ \\
$P s 367 \times P e 139(36)$ & UENFH-6 & 6,27 \\
$P s 367 \times P e 89(11)$ & UENFH-7 & $1,2,3,4,5,6,7,8,9,10,11,12,13,14$ \\
$P s 365 \times P e 139(36)$ & UENFH- 8 & $3,8,13,16,28,45,47,48,55,58,61,62,63,68,74$ \\
$P s 365 \times P e 89(7)$ & UENFH-9 & $1,3,5,9,11,12,16,21,29,36,37,38,40,47,52,53,54,55,56,57$ \\
\hline
\end{tabular}

\section{Interspecific hybridizations}

The interspecific hybridizations were held at the UESC campus in a greenhouse from July 14 to August 8,2010 . The temperature inside the house ranged from $28^{\circ}$ to $22^{\circ} \mathrm{C}$, and the relative humidity was between 60 and $98 \%$. The artificial crosses were carried out at different times, from 1:30 to 2:30 pm for the genotypes of $P$. edulis and from 7:00 to 7:30 pm for the genotypes of $P$. setacea. Flower buds of the parents were protected with paper bags in the morning. The anthers of the donor species were collected, placed on Petri dishes containing 
silica gel, and stored in the refrigerator $\left(10^{\circ} \mathrm{C}\right)$ until the occurrence of the anthesis of the flowers (anthesis at 12:30 pm in plants of $P$. edulis and from 6:00 to 7:00 pm in plants of $P$. seta$c e a$ ). During pollination, the anthers of the donor species were carefully rubbed on the stigma of the recipient species with the aid of tweezers. After artificial hybridization, the crosses were identified, and the flowers were protected again for up to $24 \mathrm{~h}$. The fruits that resulted from successful hybridizations were protected using nylon net until their full maturity.

\section{Cultivation conditions}

Individuals of different genotypes were planted in November 2011 in the experimental area of the Escola Agrícola Antônio Sarlo, northern State of Rio de Janeiro at the latitude of $21^{\circ} 45^{\prime} \mathrm{S}$ and longitude of $41^{\circ} 20^{\prime} \mathrm{W}$ and $11 \mathrm{~m}$ above sea level. The vertical cordon system was used with stakes that were $2.5 \mathrm{~m}$ in height and spaced at $4 \mathrm{~m}$ with a number 12 wire that was $1.80 \mathrm{~m}$ above the ground. The distance between the crop rows was $3.5 \mathrm{~m}$. The cultural practices recommended for the cultivation of passion fruit were followed (Viana et al., 2003).

The first fruiting occurred in March 2012. The periods of harvesting and evaluation of fruits occurred from March to July 2012. The vegetative and floral morphological characteristics were assessed throughout 2012.

Genotypes were characterized according to the list of descriptors for the registration and protection of passion fruit cultivars that was prepared by the National Service for Cultivar Protection of the Ministry of Agriculture, Livestock and Supply. Thirty-five descriptors were used; 12 were qualitative (Table 2) and 23 were quantitative.

\begin{tabular}{|c|c|}
\hline Descriptor & $\begin{array}{l}\text { Classes observed according to the descriptors for Passiflora spp } \\
\text { (Ministério da Agricultura Pecuária e Abastecimento - MAPA) }\end{array}$ \\
\hline Color of the branch & 1: light green; 2 : dark green \\
\hline Shape of the leaf & 7: broken \\
\hline Division of the leaf blade & 3: trilobate \\
\hline Leaf blade: sinus & 1: absent; 2 : present \\
\hline Depth of the sinus & 3: shallow; 5: average; 7: deep \\
\hline Leaf blade: pilosity & 1: absent; $2:$ present \\
\hline Position of leaf gland & $\begin{array}{l}\text { 1: adjacent to the leaf blade; } 2 \text { : close to the middle of the petiole; } \\
3 \text { : adjacent to the insertion of the leaf in the branch }\end{array}$ \\
\hline Prevailing corona color & 1: white; 3: red; 4: purplish-red; 5: purple; 7: dark blue; 8: lilac \\
\hline Time of anthesis & 2: evening; 3 : night \\
\hline Pulp color & 2: greenish-yellow; 3 : yellow; 4: orange-yellow; 5 : orange; 8 : light yellow \\
\hline Prevailing skin color & 1: green; 2: yellow; 4: pinkish; 7: greenish-yellow; 8: yellowish-green \\
\hline Fruit shape & 1: oval \\
\hline
\end{tabular}

\section{Quantitative descriptors}

The following quantitative descriptors and defined measurements were used: stem diameter in $\mathrm{mm}(\mathrm{SD})$, at the height of the first node of the main axis; leaf length in $\mathrm{mm}$ (LL), the longitudinal extent of the highest edge; leaf width in $\mathrm{mm}(\mathrm{LW})$, the transverse measurement of the largest dimension; petiole length in $\mathrm{mm}$ (PL), from the insertion of the stem until the insertion of the leaf; flower diameter in $\mathrm{mm}(\mathrm{FD})$, from the extreme points of the flower; corona 
diameter in $\mathrm{mm}(\mathrm{CD})$, from the extreme points of the corona filaments; length of outer series of corona filaments in $\mathrm{mm}(\mathrm{LC})$, from the insertion in the flower receptacle up to the apex; petal length in $\mathrm{mm}$ (LP), from the insertion of the flower in the apex; sepal length in $\mathrm{mm}$ (SL), from the insertion in the flower to the apex; petal width in $\mathrm{mm}(\mathrm{PW})$, the largest dimension; sepal width in $\mathrm{mm}(\mathrm{SW})$, the largest dimension; floral peduncle length in $\mathrm{mm}(\mathrm{FP})$, from the insertion in the receptacle of the flower to the insertion in the stem; androgynophore length in $\mathrm{mm}(\mathrm{AL})$, the fullest extent that sustains the sexual organs; bract length in $\mathrm{mm}(\mathrm{BL})$, from the insertion in the peduncle to the apex; number of fruits (NF) assessed in weekly harvests (for 4 months), and the total number of fruits per plant is counted at the end of the evaluation period; average fruit weight in $\mathrm{g}(\mathrm{FW})$, obtained with a digital semianalytical scale for all mature fruits that were collected during the study period; fruit longitudinal diameter in $\mathrm{mm}$ (LD), determined in the longitudinal region of the fruits with the aid of a digital caliper; fruit transverse diameter in $\mathrm{mm}$ (TD), determined in the equatorial region of the fruits using a digital caliper; shell thickness in mm (ST), determined by the arithmetic mean of the measures of four points of the outer shell in the middle portion of the fruits (transversely cut, toward the largest diameter) using a digital caliper; pulp weight in $g$ (WP), obtained by weighing the pulp (seeds with arils) with the aid of the semianalytical balance; content of total soluble solids (SST), obtained by refractometry using an ATAGO N1 portable digital refractometer with readings ranging from 0 to $32^{\circ}$ Brix; number of seeds (NS), manual counting (average of 10 fruits); and seed size in $\mathrm{mm}$ (SS), the ratio between the length and width of a sample of 10 seeds of 10 fruits.

\section{Statistical analysis}

The quantitative and qualitative variables were analyzed simultaneously using the Ward-MLM procedure to form groups of genotypes using the CLUSTER procedure and IML (Interactive Matrix Language) of the SAS software system (SAS Institute, 2000). The distance matrix was obtained by the Gower algorithm (Gower, 1971) to use Ward's clustering method. The optimal number of groups was defined according to the pseudo-F and pseudo- $\mathrm{t}^{2}$ criteria combined with the likelihood profile associated with the likelihood ratio test (SAS Institute, 2000).

The Gower dissimilarity index was used because the set of variables under study formed a mixed group. The Gower index uses qualitative and quantitative data to generate a single dissimilarity index ranging from 0 to 1 . The dissimilarity was given by the following:

$$
S i j=\frac{\sum_{k=1}^{p} W_{i j k} \cdot S_{i j k}}{\sum_{K=1}^{p} W_{i j k}}
$$

where $i$ and $j$ refer to the individuals to be compared with regard to trait $k, p$ is the total number of traits, and $S_{i j}$ is the contribution of the variable $k$ to the total distance. If a variable is qualitative, $S_{i j k}$ takes the value 1 when the concordance is positive or negative for the trait $k$ between individuals $i$ and $j$. On the other hand, when the variable is quantitative, 


$$
S_{i j}=\frac{Y_{i k}-Y_{j k}}{R_{k}}
$$

(Equation 2)

where $R_{k}$ is the range of variation of the variable $k$, with values between 0 and 1 . The value of $W_{i j k}$ was used to define the contributions of $S_{i j k}$ individuals. Thus, when the value of the variable $k$ is absent in one or both individuals, $W_{i j k}$ is 0 ; otherwise, it is equal to 1.

\section{RESULTS AND DISCUSSION}

\section{Ward-MLM method}

The Ward-MLM procedure, which uses both quantitative and qualitative variables, was used to distinguish 138 genotypes. According to the pseudo-F and pseudo- $\mathrm{t}^{2}$ criteria, three was defined as the optimal number of groups. This is due to the increase in the likelihood function observed in group III, i.e., 196.03 (Figure 1).

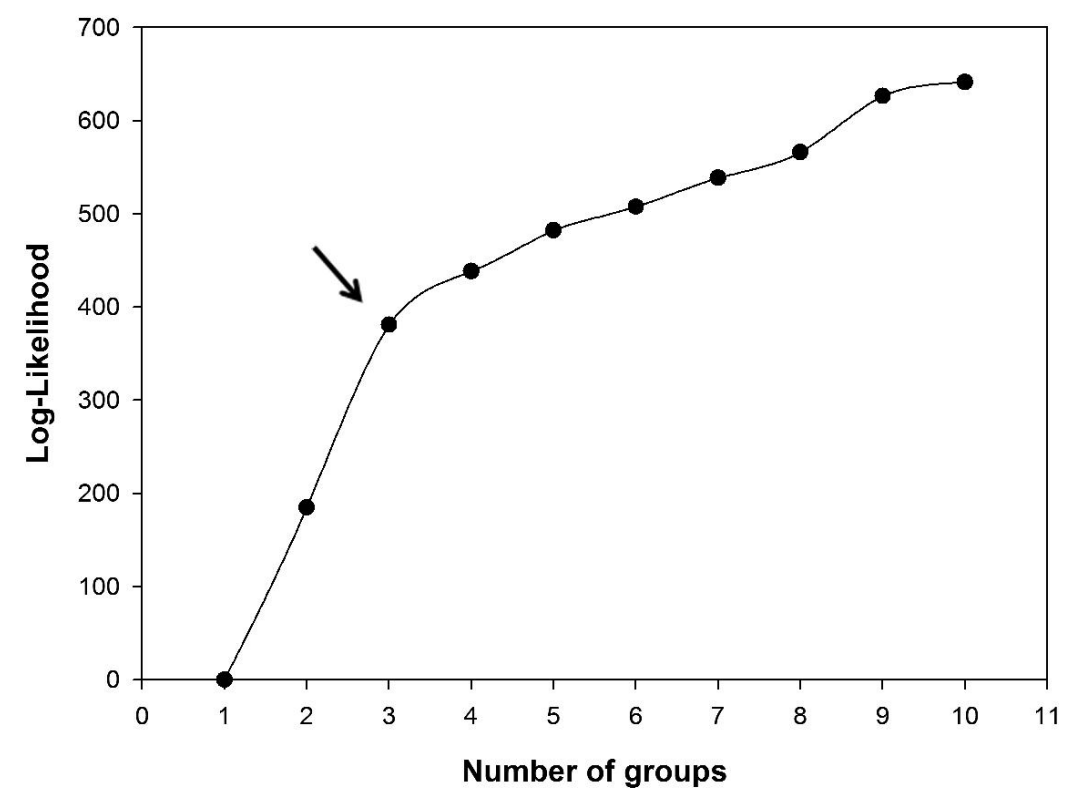

Figure 1. Graph of the logarithmic likelihood function (log-likelihood) relative to the number of groups formed by the Ward-modified location model (MLM) strategy in Passiflora edulis, P. setacea, and $\mathrm{S}_{0}$ interspecific hybrids.

The analysis of the likelihood function can define precise criteria to form groups, which results in few subjective groupings. The same is not true for most of the other clustering methods, in which the number of groups is established personally (Gonçalves et al., 2009). Sudré et al. (2010) evaluated 56 accessions of Capsicum from the germplasm bank of the 
UENF and set five as the optimal number of groups because the maximum value was reached at this point. Pestana et al. (2011) analyzed 74 banana mutants and observed greater increases in the probability function in group III, which agrees with the findings of this study. In turn, Campos et al. (2013) evaluated a population of 138 Psidium guajava individuals from the UENF breeding program and found that the greatest increase in the probability function was achieved when five groups were considered. The number of groups may vary according to the species, number of accessions, and number and type of descriptors (Gonçalves et al., 2009).

The Ward-MLM classification strategy for the analysis of the morphoagronomic data allowed the separation of 138 genotypes into three homogeneous groups that were formed according to their similarities. Group I was composed of 118 hybrid genotypes, group II was composed of 10 P. setacea genotypes, and group III was composed of 10 P. edulis genotypes. The clear separation between the groups indicates that the morphoagronomic traits efficiently discriminated the parents and their hybrids. Santos et al. (2012) evaluated the morphological diversity in Passiflora sublanceolata (e.g., Passiflora palmeri var. sublanceolata), Passiflora foetida, and their hybrids, and the observed clear separation between these species and the segregating population.

The interspecific hybrids, which were placed in group I, had wide variability in all traits under study. All representatives of this group presented leaves that were broken, trilobate, glabrous, and light green and had glands in the middle of the petiole (Figure 2b). Most genotypes $(98.30 \%$ ) had a deep leaf sinus (Table 3 and Figure $2 b$ ).
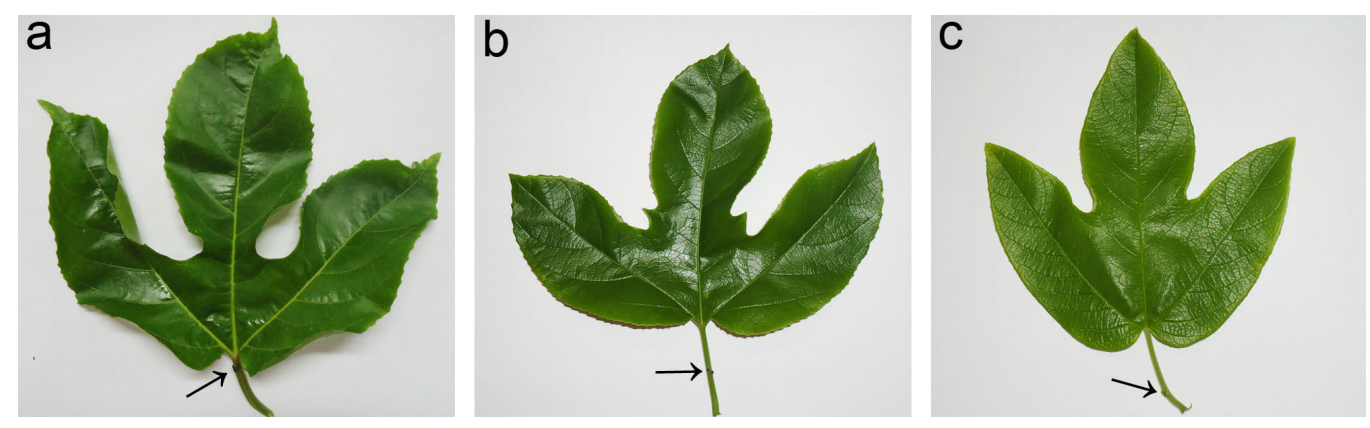

Figure 2. Qualitative descriptors for leaf in the genotypes of Passiflora edulis, P. setacea, and $\mathrm{S}_{0}$ interspecific hybrids. a. P. edulis (glands adjacent to the leaf blade); b. interspecific hybrid (glands located in the middle of the petiole); and c. . setacea (glands located near the insertion of the leaf on the branch). The arrows indicate the position of the glands.

There was no synchrony in flower opening. Anthesis started around 1:30 pm and went until 3:00 pm, when all the flowers were open. The corona presented a wide variety of colors that included white and dark blue. However, the purplish-red color was the most prevalent in the population $(77.11 \%)$ and was followed by purple (11.01\%), dark blue $(8.47 \%)$, white $(1.69 \%)$, and red $(1.69 \%)$ (Table 3 and Figure $3 \mathrm{c}-1)$.

Similar results were obtained by Junqueira et al. (2005) in midwestern Brazil. The authors evaluated $98 \mathrm{~S}_{0}$ plants that were obtained from crosses between P. edulis and P. setacea using passion fruit as a male or female parent, and they observed light green leaves, high flowering capacity, and corona in shades of lilac in the segregating population. 
Table 3. Descriptors and number of genotypes per group of qualitative traits in each of the three groups (GI, GII, and GIII) formed by the Ward-modified location model (MLM) strategy in Passiflora edulis, P. setacea, and $\mathrm{S}_{0}$ interspecific hybrids.

\begin{tabular}{|c|c|c|c|}
\hline \multirow[t]{2}{*}{ Descriptors } & \multicolumn{3}{|c|}{ Groups } \\
\hline & GI (118) & GII (10) & GIII (10) \\
\hline \multicolumn{4}{|l|}{ Color of the branch } \\
\hline Light green & 118 & 10 & - \\
\hline Dark green & - & - & 10 \\
\hline \multicolumn{4}{|l|}{ Depth of the sinus } \\
\hline Shallow & - & 10 & - \\
\hline Average & 2 & - & - \\
\hline Deep & 116 & - & 10 \\
\hline \multicolumn{4}{|l|}{ Position of the gland } \\
\hline Adjacent to the leaf blade & - & - & 10 \\
\hline Middle of the petiole & 118 & - & - \\
\hline Adjacent to the insertion of the leaf to the branch & - & 9 & - \\
\hline Distributed along the petiole & - & 1 & - \\
\hline \multicolumn{4}{|l|}{ Color of the corona } \\
\hline White & 2 & 10 & - \\
\hline Red & 2 & - & - \\
\hline Purplish-red & 91 & - & - \\
\hline Purple & - & - & 10 \\
\hline Lilac & 13 & - & - \\
\hline Dark blue & 10 & - & - \\
\hline \multicolumn{4}{|l|}{ Time of anthesis } \\
\hline Evening & 118 & - & 10 \\
\hline Night & - & 10 & - \\
\hline \multicolumn{4}{|l|}{ Color of the pulp } \\
\hline Greenish-yellow & - & 5 & - \\
\hline Yellow & 53 & - & 1 \\
\hline Orange-yellow & 33 & 2 & 6 \\
\hline Orange & 18 & - & 3 \\
\hline Light yellow & 14 & 3 & - \\
\hline \multicolumn{4}{|l|}{ Color of the skin } \\
\hline Green & 43 & 10 & - \\
\hline Yellow & 15 & - & 7 \\
\hline Pinkish & - & - & 2 \\
\hline Greenish-yellow & 14 & - & - \\
\hline Yellowish-green & 46 & - & 1 \\
\hline \multicolumn{4}{|l|}{ Fruit shape } \\
\hline Oval & 116 & 4 & 6 \\
\hline Round & 2 & - & 4 \\
\hline Ellipsoid & - & 6 & - \\
\hline
\end{tabular}

Regarding qualitative fruit descriptors, the color of the skin of ripe fruits ranged from green to yellow. However, the yellowish-green color prevailed in genotypes of this group (38.98\%) and was followed by green (36.44\%), yellow (12.71\%), and yellow-greenish (11.86\%) (Table 3 and Figure 4a). As for the fruit shape, the oval shape stood out in this group and was observed for $98.30 \%$ of the individuals (Table 3 and Figure $4 d$ ). The color of the pulp ranged from light yellow to orange, but yellow was predominant in hybrid genotypes $(44.90 \%)$, followed by yellow-orange (27.96\%), orange (15.25\%), and light yellow (11.86\%) (Table 3 and Figure $5 \mathrm{~g}-\mathrm{j}$ ).

In opposition to the results obtained in this work, Junqueira et al. (2005) observed that the $\mathrm{S}_{0}$ population (P. edulis $\mathrm{x}$ P. setacea) only produced fruit by hand pollination. The authors attributed this to the fact that plants had a very long androgynophore and that anthesis started around 5:00 pm, which prevented pollination by insects. In this study, the size of the androgynophore and time of anthesis of hybrid plants were not considered to be limiting factors for fruit production. 

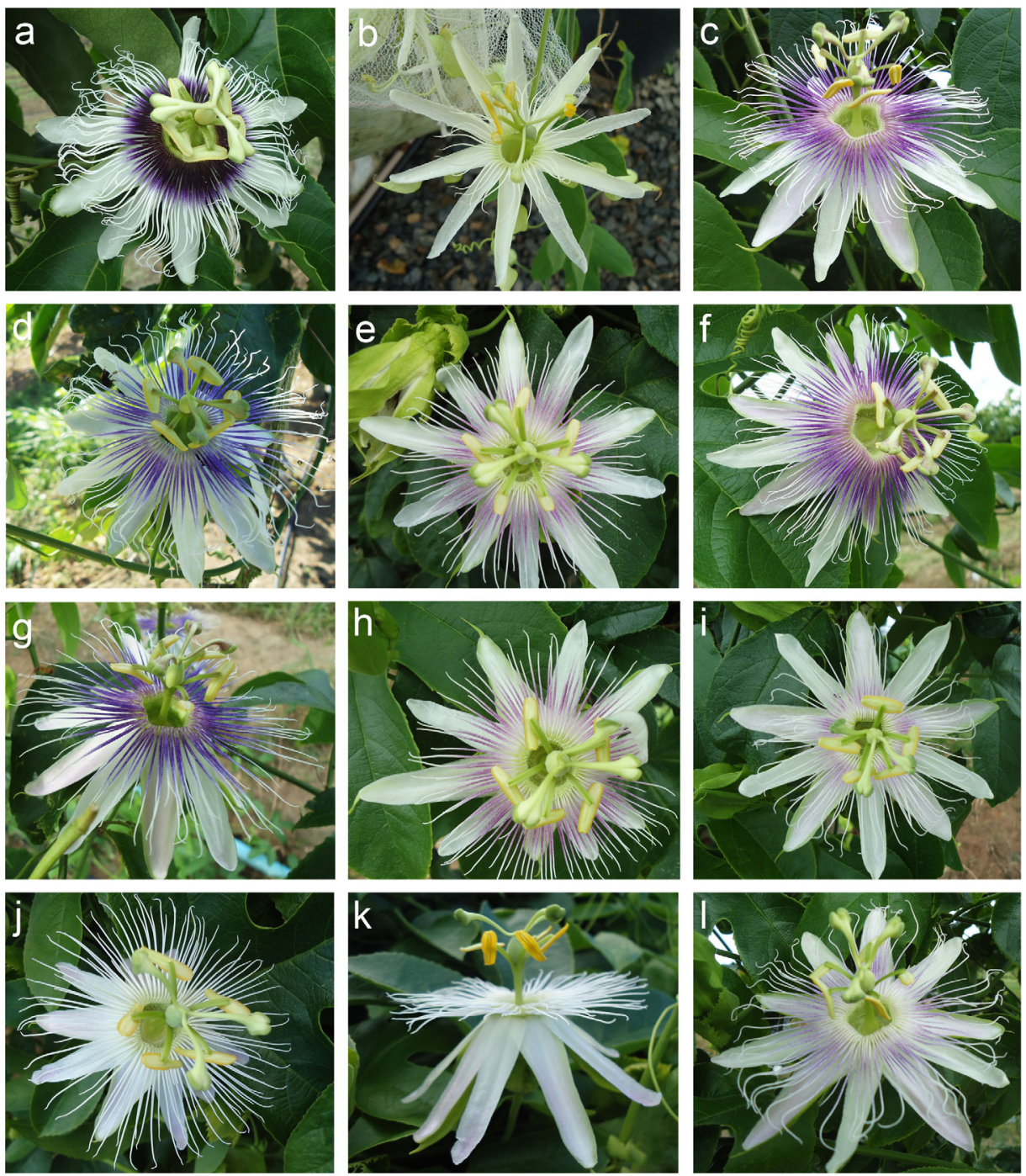

Figure 3. Qualitative descriptors for flower in the genotypes of Passiflora edulis, P. setacea, and $\mathrm{S}_{0}$ interspecific hybrids. Predominant color of the corona: a. P. edulis purple; b. P. setacea white; c.-l. interspecific hybrids: $\mathrm{c}$ and $\mathrm{f}$ purplish-red; $\mathrm{d}$ and $\mathrm{g}$ - dark blue; $\mathrm{e}$ and $\mathrm{h}$ - red; i and $\mathrm{l}$ - lilac; and $\mathrm{j}$ and $\mathrm{k}$ - white.

Regarding the quantitative traits, group I contained the genotypes with the highest values for the floral traits FD, CD, LC, LP, SL, and BL (101.44, 79.33, 35.40, 41.01, 46.45, and 28.53, respectively) and the lowest values for the vegetative traits LL (118.02) and PL (44.25). As for the agronomic descriptors of the fruits, the individuals of this group contained high values for SS and low values for NF (13.52), WP (23.00), and NS (57.47) (Table 4). Regarding the traits AL, FW, TD, LD, ST, and SST, the hybrids had values that were intermediate compared to those of the parents (Table 4). 

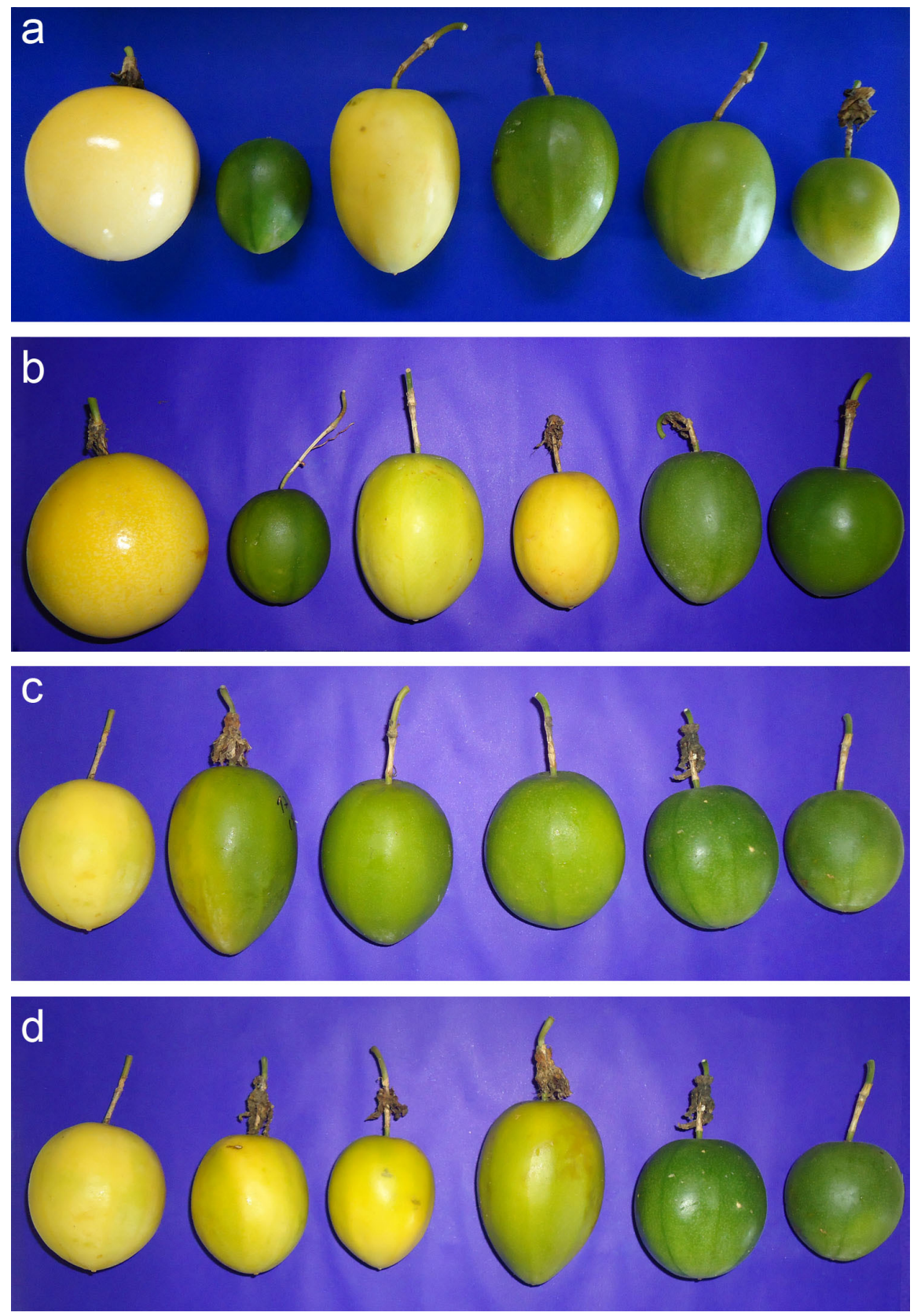

Figure 4. Qualitative descriptors for fruits in the genotypes of Passiflora edulis, P. setacea, and $\mathrm{S}_{0}$ interspecific hybrids. a. Color of fruit (left to right): $P$. edulis - yellow, P. setacea - green, and interspecific hybrids - first: yellow and the last three: yellowish-green. b. Fruit shape (left to right): P. edulis - round, P. setacea - oval, and interspecific hybrids - first three: oval and fourth: round. c. Color of fruit: interspecific hybrids - first: yellow, second: greenishyellow, third and fourth: yellowish-green, and fifth and sixth: green. d. Shape of fruit: interspecific hybrids - first five: oval and last: round. 

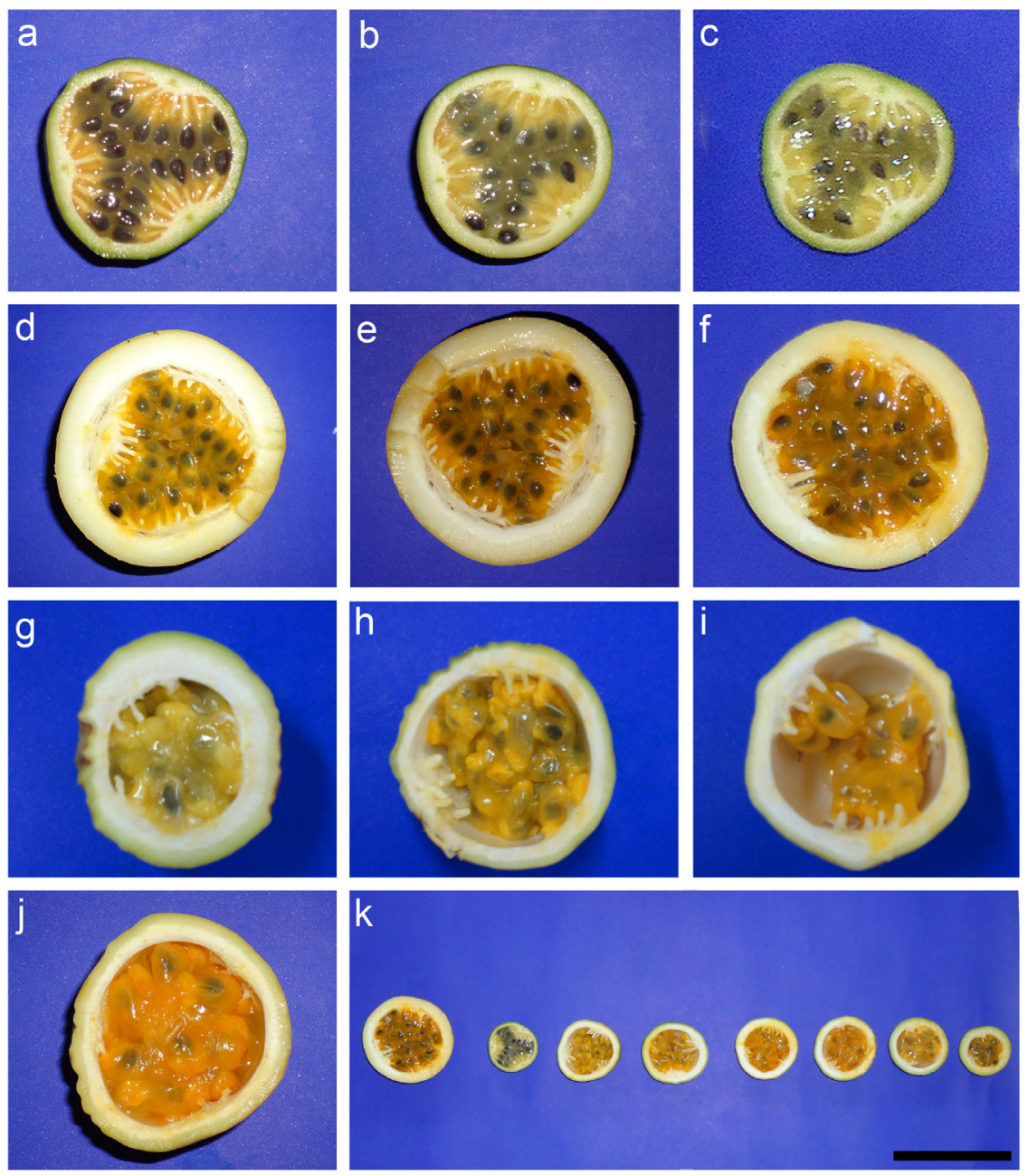

Figure 5. Qualitative descriptors for color of the pulp in the genotypes of Passiflora setacea, P. edulis, and interspecific hybrids: a. orange-yellow; b. light yellow; c. greenish-yellow; d. yellow; e. orange-yellow; f. orange; g. light yellow; h. yellow; i. orange-yellow; j. orange; k. cross section of fruits of $P$. edulis, $P$. setacea, and $\mathrm{S}_{0}$ interspecific hybrids. Bar in $\mathrm{k}$ equals $10 \mathrm{~cm}$.

The low NF value is probably associated with the elevated height of the stigma in relation to the corona because of the long androgynophore, which hinders pollination. Thus, in this population, it is important to assess the androgynophore length to select plants with a shorter androgynophore.

In passion fruit, pollination affects fruiting because the NS per fruit and pulp yield are correlated with the number of pollen grains deposited on the stigma during pollination (Akamine and Girolami, 1959). Therefore, in this group, the low values for WP and NS may result from the small amount of pollen deposited on the stigma. This may be due to the average length of the hybrid plant androgynophore, which was $16.10 \mathrm{~mm}$. Although smaller than 
that of P. setacea $(24.29 \mathrm{~mm}$, group II), it is still large compared to that of P. edulis $(6.96 \mathrm{~mm}$, group III). The bees of the genus Xylocopa, known as carpenter bees, are the effective pollinators at the time of anthesis of this group. They are known as mamangavas and are the same species that pollinates sour passion fruit. Thus, the distance between the dehiscent front of anthers does not allow precise coupling on the dorsal region of pollinators, which decreases the number of pollen grains deposited on the stigma. This should not occur in individuals of group II because pollinators (bats and moths) are larger and can perform a more efficient pollination. At the time of the anthesis of $P$. setacea, the stigma of hybrid plants may not be receptive, thus hindering pollination. However, this should be further investigated because this group comes from interspecific crosses and other factors may be involved.

Table 4. Means of quantitative variables for each of the three groups formed by the Ward-modified location model (MLM) method and eigenvalues of the two canonical variables (CAN) in Passiflora edulis, P. setacea, and $\mathrm{S}_{0}$ interspecific hybrids.

\begin{tabular}{|c|c|c|c|c|c|}
\hline \multirow[t]{2}{*}{ Descriptors } & \multicolumn{3}{|c|}{ Groups } & \multicolumn{2}{|c|}{$\mathrm{CAN}$} \\
\hline & GI (118) & GII (10) & GIII (10) & CAN1 & CAN2 \\
\hline $\mathrm{SD}(\mathrm{mm})$ & 27.06 & 16.81 & 28.96 & 0.37 & 0.40 \\
\hline LL (mm) & 118.02 & 118.53 & 149.12 & 0.36 & -0.16 \\
\hline $\mathrm{LW}(\mathrm{mm})$ & 148.50 & 114.90 & 166.02 & 0.34 & 0.21 \\
\hline PL (mm) & 44.26 & 48.98 & 74.20 & 0.39 & -0.26 \\
\hline $\mathrm{FD}(\mathrm{mm})$ & 101.44 & 83.86 & 89.98 & -0.01 & 0.63 \\
\hline $\mathrm{CD}(\mathrm{mm})$ & 79.33 & 52.25 & 77.59 & 0.39 & 0.69 \\
\hline $\mathrm{LC}(\mathrm{mm})$ & 35.40 & 22.32 & 33.18 & 0.01 & 0.09 \\
\hline $\mathrm{LP}(\mathrm{mm})$ & 41.01 & 32.67 & 36.32 & 0.05 & 0.78 \\
\hline $\mathrm{SL}(\mathrm{mm})$ & 46.45 & 39.20 & 38.64 & -0.16 & 0.63 \\
\hline $\mathrm{SW}(\mathrm{mm})$ & 14.30 & 9.44 & 14.47 & 0.45 & 0.63 \\
\hline PW (mm) & 10.65 & 7.77 & 10.96 & 0.28 & 0.37 \\
\hline $\mathrm{FP}(\mathrm{mm})$ & 75.08 & 108.54 & 52.54 & -0.63 & -0.29 \\
\hline $\mathrm{AL}(\mathrm{mm})$ & 16.10 & 24.29 & 6.96 & -0.95 & -0.18 \\
\hline $\mathrm{BL}(\mathrm{mm})$ & 28.53 & 18.53 & 25.90 & 0.24 & 0.70 \\
\hline $\mathrm{NF}$ & 13.52 & 14.89 & 51.70 & 0.46 & -0.26 \\
\hline FW (g) & 63.40 & 43.35 & 157.48 & 0.84 & -0.26 \\
\hline $\mathrm{TD}(\mathrm{mm})$ & 56.97 & 40.41 & 73.03 & 0.79 & 0.22 \\
\hline $\mathrm{LD}(\mathrm{mm})$ & 70.94 & 50.74 & 81.50 & 0.58 & 0.34 \\
\hline ST (mm) & 5.40 & 2.78 & 6.25 & 0.56 & 0.46 \\
\hline $\mathrm{WP}(\mathrm{g})$ & 23.00 & 25.38 & 77.03 & 0.78 & -0.48 \\
\hline SST ( ${ }^{\circ}$ Brix $)$ & 13.31 & 17.84 & 13.05 & -0.46 & -0.61 \\
\hline NS & 57.47 & 168.61 & 317.67 & 0.58 & -0.78 \\
\hline $\mathrm{SS}(\mathrm{mm})$ & 5.11 & 4.29 & 5.06 & 0.37 & 0.65 \\
\hline
\end{tabular}

$\mathrm{SD}=$ stem diameter; $\mathrm{LL}=$ leaf length; $\mathrm{LW}=$ leaf width; $\mathrm{PL}=$ petiole length; $\mathrm{FD}=$ flower diameter $\mathrm{CD}=$ corona diameter; $\mathrm{LC}=$ length of the outer series of corona filaments; $\mathrm{LP}=$ petal length; $\mathrm{SL}=$ sepal length; $\mathrm{SW}=$ sepal width; $\mathrm{PW}=$ petal width; $\mathrm{FP}=$ floral peduncle length; $\mathrm{AL}=$ length of androgynophore; $\mathrm{BL}=$ length of bract; $\mathrm{NF}=$ number of fruits; $\mathrm{FW}=$ fruit weight; $\mathrm{TD}=$ transverse diameter of the fruit; $\mathrm{LD}=$ longitudinal diameter of the fruit; $\mathrm{ST}=$ skin thickness; $\mathrm{WP}=$ pulp weight; $\mathrm{SST}=$ content of total soluble solids; $\mathrm{NS}=$ number of seeds; $\mathrm{SS}=$ seed size.

Group II consists of the 10 genotypes of P. setacea and presents leaves that are broken, trilobate, glabrous, and light green with a shallow leaf sinus. Nine of the 10 individuals studied have petiole glands located near the insertion of the leaf in the branch (Table 3 and Figure 2c). The same description was obtained in a survey of the Passifloraceae family for P. setacea in the State of Bahia (Nunes and Queiroz, 2006).

Anthesis is nocturnal and synchronous for all individuals. It starts about 7:00 pm (Table 3). The same floral opening time was reported by Junqueira et al. (2005) for P. setacea in the Federal District. 
The color of the corona in this group was predominantly white (Table 3 and Figure $3 b$ ), which differs from the description of white corona filaments with blue bands that was mentioned by Nunes and Queiroz (2006). The green ripe fruit skin was prevalent in this group (Figure 4a). Concerning fruit shape, $60 \%$ of the genotypes have an ellipsoid shape (Table 3 and Figure $4 \mathrm{~b}$ ). The shape and color of fruits were similar to those described by Nunes and Queiroz (2006) for P. setacea. With regard to pulp color, three categories have been reported, but the predominant color in this group was greenish yellow (50\%), followed by light yellow (30\%) and orange-yellow (20\%) (Table 3 and Figure 5a-c).

With respect to the quantitative descriptors, this group presented the lowest values for SD (16.81), LW (114.90), and the following traits related to flowers: FD, CD, LC, LP, SW, PW, and BL (83.86, 52.25, 22.32, 32.67, 9.44, 7.77, and 18.53, respectively). The highest values were obtained for FP and AL, which were 108.74 and 24.29, respectively. Regarding the quantitative floral morphological descriptors, the values described by Nunes and Queiroz (2006) for FP (60-120 mm), BL (10-20), FD (50-100), LC (20-25), and AL (25-35) are similar to those obtained in this study (Table 4). Smaller and lighter fruits, as well as thinner skin and smaller seed size were found in group II than in other groups, with low values for FW, TD, LD, ST, and SS $(43.35,40.41,50.74,2.78$, and 4.29 , respectively). On the other hand, the highest mean SST (17.84) was obtained in this group (Table 4).

The sleep passion fruit is an excellent source of genetic resistance to plant pathogens that affect passion fruit crops. Thus, it is widely used in sour passion fruit breeding programs to transfer resistance genes to the commercial species (Cerqueira-Silva et al., 2009). The production of sleep passion fruit is restricted to areas where the species occur and are sold in a small domestic scale. In the municipalities of Curaçá, Uauá, and Canudos in the State of Bahia, this fruit is used for both fresh consumption and the production of jams and jellies that are manufactured in processing industries (Cerqueira-Silva et al., 2012). Thus, studies that seek to characterize wild species morphoagronomically are fundamental in the pre-breeding stage because they generate potentially useful information about the organoleptic properties of fruits and contribute to the dissemination and use of new species for consumption.

In this study, the average values for FW, TD, and LD were similar to those obtained for genotypes of $P$. setacea that were investigated in southwestern Bahia (Cerqueira-Silva et al., 2009). As for the average skin thickness, which is intended to be reduced, the value that was obtained in this study was lower than that found by Cardoso-Silva et al. (2007) and was similar to that reported by Cerqueira-Silva et al. (2009). Higher levels of SST, above 13 ${ }^{\circ}$ Brix, are desirable for the juice industry (Fortaleza et al., 2005). The average SST reported in this study was similar to that found for sleep passion fruit genotypes that were assessed in southwestern Bahia (Cerqueira-Silva et al., 2009). A thin shell and high soluble solid content are traits that can be included in the passion fruit breeding program to improve fruit quality.

Group III was formed by the 10 cultivars of $P$. edulis. All individuals in this group have leaves that are broken, trilobate, glabrous, and dark green and present a deep leaf sinus and petiole glands adjacent to the leaf blade (Table 3 and Figure 2a); similar observations of $P$. edulis were reported by Cervi and Linsingen (2008). Purple was the predominant corona color in all individuals (Table 3 and Figure 3a), which was also noted by Crochemore et al. (2003) and Nunes and Queiroz (2006), who assessed passion fruit trees from the States of Paraná and Bahia, respectively. The flowers of this group showed no synchrony with floral opening, but flowers started a period of anthesis about 12:00 pm. The beginning of the anthesis period coincides with that found for the sour passion fruit in northern Rio de Janeiro State (Benevi- 
des et al., 2009) and in Juazeiro, BA (Siqueira et al., 2009). Souza et al. (2012) studied the reproductive phenology of sour passion fruit from September 2009 to September 2010 under the conditions of the municipality of Campos dos Goytacazes, and they found that flowering occurred from October to March, when the highest average temperatures were observed, with a peak in January and highest percentage of ripe fruit in February.

Regarding the qualitative descriptors of the fruits, yellow was the prevailing skin color $(70 \%)$, followed by pink $(20 \%)$ and yellowish-green (10\%) (Table 3 and Figure 4a). Cervi and Linsingen (2008) reported wide variation in the fruit skin color of $P$. edulis: yellow, greenish-yellow, red, and purple. The oval fruit shape prevailed in this group and was observed for $60 \%$ of individuals (Table 3 and Figure $4 \mathrm{~b}$ ); this observation agrees with the findings of Cervi and Linsingen (2008). Oval passion fruits have always been preferably selected because they are more marketable and have higher yield for juice than other fruit shapes. Meletti et al. (2000) recommend the selection of plants with ovate fruits because they have high juice content. However, Negreiros et al. (2007) found that pulp yield was not correlated with fruit shape.

The pulp color ranged from yellow to orange, but orange-yellow $(60 \%)$ predominated in the genotypes (Table 3 and Figure 5d-f). Variations in the color of the skin and fruit pulp were also observed by Crochemore et al. (2003) for P. edulis. The color of passion fruit skin was used to distinguish the yellow and purple passion fruits. Today, this distinction is not accepted because the external color of the fruit is a trait of complex inheritance, which allows a wide variety of intermediate colors (Bernacci et al., 2008).

Regarding quantitative descriptors, this group presented the highest values for the vegetative traits SD, LL, LW, and PL $(28.96,149.12,166.02$, and 74.20 , respectively) and for the flower traits SW and PW (14.47 and 10.96, respectively) (Table 4). The lowest values for floral traits were 52.54 and 6.96 for FP and AL, respectively (Table 4). In this study, the values obtained for the vegetative and floral traits were higher than those reported by Cervi and Linsingen (2008).

The length of the androgynophore is an important trait and should be considered in morphoagronomic assessments of sour passion fruit because it is directly linked to pollination, which, in turn, is related to production. This is the first study that investigated this trait in sour passion fruit. Short androgynophores reduce the height of the stigmas in relation to the corona, thus favoring pollination. At the time of maximum curvature of the stylet, stigmas even touch the corona, and thus, can be easily pollinated by smaller bees (Siqueira et al., 2009).

Group III obtained the highest values for NF, FW, TD, LD, ST, WP, and NS (51.70, $157.48,73.03,81.50,6.25,77.03$, and 317.67, respectively). However, the lowest value for SST (13.05) was obtained in this group (Table 4).

Since the 1980s, the genetic breeding of sour passion fruit has led to increased means of agronomic traits, productivity, and fruit quality in each niche market. Heavy, larger, sweeter, and less acidic sour passion fruits are desirable for fresh consumption, while the industry prefers fruits with higher juice yield and high content of soluble solids (Meletti, 2011). The contents of soluble solids indicate the amount of solids dissolved in the pulp; in general, high SST contents are desirable for industrial purposes because they require less sugar (Farias et al., 2005). In this study, we found higher values for FW, LD, and SST than those obtained by Silva et al. (2012) while evaluating 144 full-sib progenies derived from the second cycle of recurrent selection. Abreu et al. (2009) found values that were lower than those obtained in this study for FW, WP, SST, and NS for the cultivar Gigante Amarelo. 
When searching for sour passion fruits with improved qualities, thin skin is a desirable trait. Breeding programs seek to select genotypes with reduced skin thickness, which may indicate a greater amount of pulp for the populations studied. Negreiros et al. (2008) report that both the juice industry and the fresh fruit market regard skin thickness as a relevant factor in fruit ranking because it is inversely proportional to juice yield. The hybrid EC-L-7 (Sul Brasil x Marília), which was rated by Abreu et al. (2009), showed an average skin thickness of $7.0 \mathrm{~mm}$ and a WP value of $37.75 \mathrm{~g}$. In this study, group III obtained an average skin thickness of $6.6 \mathrm{~mm}$ and a WP value of $77.03 \mathrm{~g}$, which indicates that selection over time was effective for these traits.

Akamine and Girolami (1959) found a positive correlation between the NS per fruit and juice content; thus, a larger NS tends to provide higher yields of juice. The average NS per fruit obtained in this study was similar to that found by Santos et al. (2009), who assessed 20 half-sib progenies of sour passion fruit.

The first two canonical (CAN) variables that were obtained by the Ward-MLM method explained $91.65 \%$ of the total variation (Figure 6). This high value indicates that a two-dimensional graph is suitable for viewing the relationships between groups and between genotypes within groups. The traits that contributed most to the genetic divergence based on the first CAN variable were AL, FW, TD, and WP (-0.95, 0.84, 0.79, and 0.78, respectively) (Table 4).

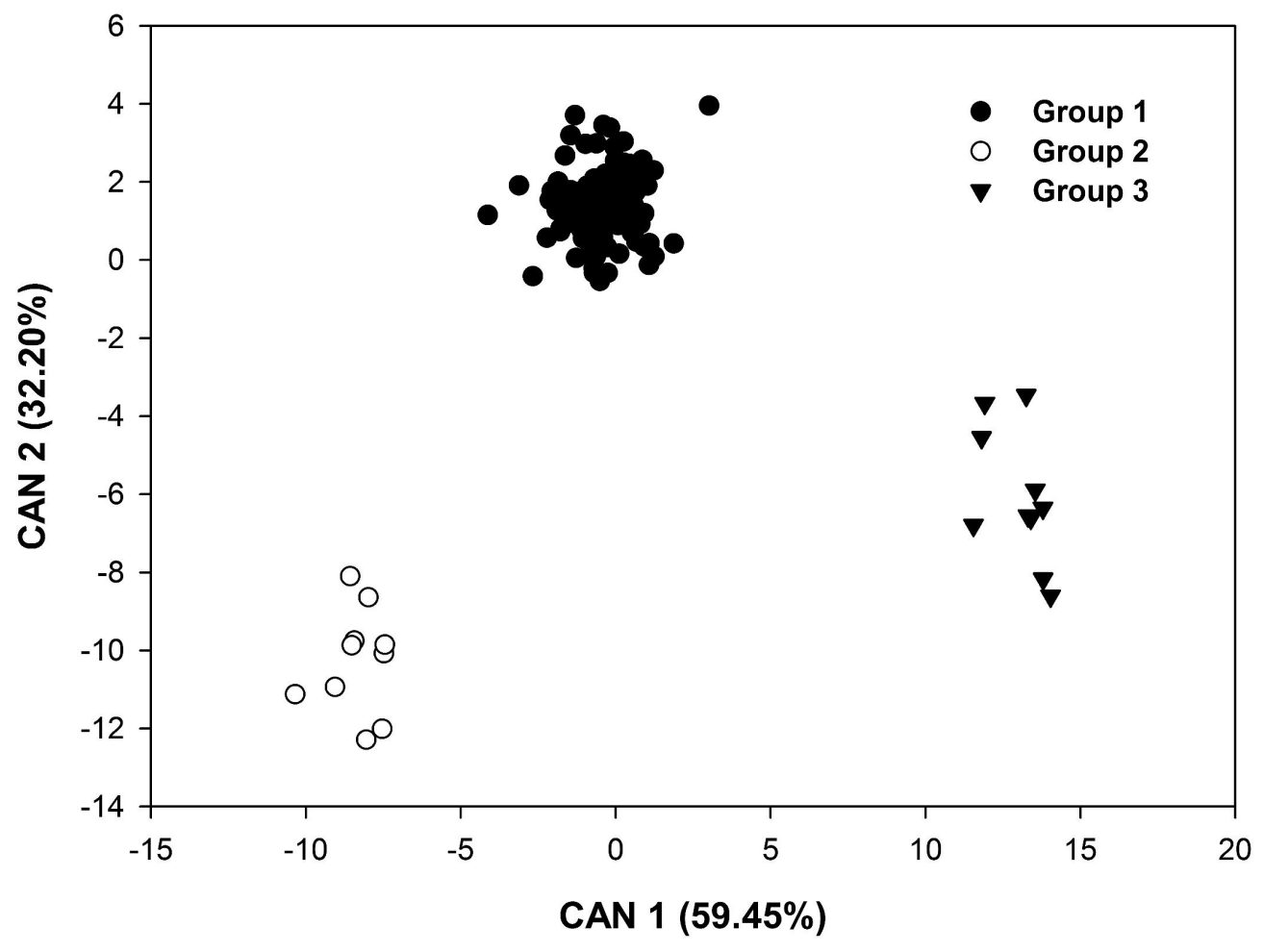

Figure 6. Graph of the first two canonical (CAN) variables for the three groups formed by the Ward-modified location model (MLM) analysis in Passiflora edulis, P. setacea, and $\mathrm{S}_{0}$ interspecific hybrids. 
CAN graphical analysis provided the highest dissimilarity at the interspecific level between groups II (P. setacea) and III (P. edulis) (Figure 6), with a distance of 474.96 (Table 5 ). The high dissimilarity between genotypes of sour passion fruit and sleep passion fruit may result from the differences between these two groups, which were demonstrated by the morphoagronomic traits. Similar results were obtained by Cerqueira-Silva et al. (2009) when they analyzed intraspecific and interspecific genetic diversity among genotypes of sour passion fruit and sleep passion fruit through physicochemical descriptors of fruits. In turn, the shortest distance between groups was observed between groups I and II (198.78) (Table 5), which showed very similar values for almost all traits. This indicates that the segregating population is genetically closer to $P$. setacea than $P$. edulis and that a higher proportion of the P. setacea genome is found in segregating individuals.

Table 5. Distance between the groups formed by the Ward-modified location model (MLM) procedure proposed
by Franco et al. (1998).
\begin{tabular}{lcc}
\hline Groups & I & II \\
\hline II & 198.78 & 474.96 \\
\hline
\end{tabular}

This study aimed to provide information that will support future crossings between individuals from groups I and III. In this case, to recover the commercial traits of sour passion fruit, we suggest crossing the best individuals of each group, i.e., the genotypes with the best agronomic traits, to aggregate value in fruit marketing and continue the passion fruit genetic breeding program at UENF.

Similar interspecific characterizations have not been reported so far. This is the first research that assesses interspecific genetic diversity through simultaneous analysis of morphoagronomic descriptors using $P$. edulis, . setacea, and their hybrids.

\section{ACKNOWLEDGMENTS}

The authors are thankful to the Graduate Program in Genetics and Plant Breeding and the Coordination of Improvement of Higher Education Personnel (CAPES) for the scholarship of the first author; to the Foundation for Research Support of the State of Rio de Janeiro (FAPERJ), the National Council for Scientific and Technological Development (CNPq), and the Universidade Estadual do Norte Fluminense Darcy Ribeiro (UENF) for their financial support of this research; and to Dr. Margarete Magalhães de Souza for providing genotypes of Passiflora setacea and the greenhouse to perform the crossovers (Universidade Estadual de Santa Cruz, BA, Brazil).

\section{REFERENCES}

Abreu SPM, Peixoto JR, Junqueira NTV and Souza MAF (2009). Características agronômicas de seis genótipos de maracujazeiro-azedo cultivados no Distrito Federal. Rev. Bras. Frutic. 31: 920-924.

Akamine EK and Girolami G (1959). Pollination and Fruit Set in the Yellow Passion Fruit. University of Hawaii, Honolulu. Barbé TC, Amaral Júnior AT, Gonçalves LSA, Rodrigues R, et al. (2010). Association between advanced generations and genealogy in inbred lines of snap bean by the Ward-Modified Location Model. Euphytica 173: 337-343. 
Bellon G, Faleiro FG, Peixoto JR, Junqueira KP, et al. (2009). Variabilidade genética de acessos obtidos de populações cultivadas e silvestres de maracujazeiro-doce com base em marcadores RAPD. Rev. Bras. Frutic. 31: 197-202.

Benevides CR, Gaglianone MC and Hoffmann M (2009). Visitantes florais do maracujá-amarelo (Passiflora edulis $f$. flavicarpa Deg. Passifloraceae) em áreas de cultivo com diferentes proximidades a fragmentos florestais na região Norte Fluminense, RJ. Rev. Bras. Entomol. 53: 415-421.

Bernacci LC, Soares-Scott MD, Junqueira NTV, Passos IRS, et al. (2008). Passiflora edulis Sims: the correct taxonomic way to cite the yellow passion fruit (and of others colors). Rev. Bras. Frutic. 30: 566-576.

Campos BM, Viana AP, Quintal SSR, Gonçalves LSA, et al. (2013). Quantificação da divergência genética entre acessos de goibeira por meio da estratégia Ward-MLM. Rev. Bras. Frutic. 35: 571-578.

Cardoso-Silva CB, Melo JRF, Pereira AS, Cerqueira-Silva CBM, et al. (2007). Estudo da diversidade genética mediante caracterização físico-química de frutos de maracujazeiros-do-sono nativos da Bahia. Magistra 19: 352-358.

Cerqueira-Silva CBM, Cardoso-Silva CB, Nonato JVA, Corrêa RX, et al. (2009). Genetic dissimilarity of 'yellow' and 'sleep' passion fruit accessions based on the fruits physical-chemical characteristics. Crop Breed. Appl. Biotechnol. 9: 210-218.

Cerqueira-Silva CB, Santos ES, Conceição LD, Cardoso-Silva CB, et al. (2012). Genetic variation in a wild population of the 'sleep' passion fruit (Passiflora setacea) based on molecular markers. Genet. Mol. Res. 11: 731-738.

Cervi AC and Linsingen LV (2008). Sinopse taxonômica das Passifloraceae Juss. no complexo de cerrado (savana) no estado do Paraná - Brasil. Iheringia Ser. Bot. 63: 145-157.

Crochemore ML, Molinari HBC and Vieira LGE (2003). Genetic diversity in passion fruit (Passiflora spp.) evaluated by RAPD markers. Braz. Arch. Biol. Technol. 46: 521-527.

Farias MAA, Faria GA, Cunha MAP, Peixoto CP, et al. (2005). Caracterização física e química de frutos de maracujáamarelo de ciclos de seleção massal estratificada e de populações regionais. Magistra 17: 83-87.

Fortaleza JM, Peixoto JR, Junqueira NTV, Oliveira AT, et al. (2005). Características físicas e químicas em nove genótipos de maracujá-azedo cultivado sob três níveis de adubação potássica. Rev. Bras. Frutic. 27: 124-127.

Franco J, Crossa J, Villaseñor J, Taba S, et al. (1998). Classifying genetic resources by categorical and continuous variables. Crop Sci. 38: 1688-1696.

Gonçalves LS, Rodrigues R, Amaral AT Jr, Karasawa M, et al. (2008). Comparison of multivariate statistical algorithms to cluster tomato heirloom accessions. Genet. Mol. Res. 7: 1289-1297.

Gonçalves LS, Rodrigues R, do Amaral Junior AT, Karasawa M, et al. (2009). Heirloom tomato gene bank: assessing genetic divergence based on morphological, agronomic and molecular data using a Ward-modified location model. Genet. Mol. Res. 8: 364-374.

Gower JC (1971). A general coefficient of similarity and some of its properties. Biometrics 27: 857-871.

IBGE (2011). Banco de Dados Agregados: Produção Agrícola Municipal. Instituto Brasileiro de Geografia e Estatística, Rio de Janeiro. Available at [http://www.sidra.ibge.gov.br./bda/tabela/protabl.asp?c=1613\&z=p\&o=23\&i=P.]. Accessed January 23, 2013.

Junqueira NTV, Braga MF, Faleiro FG, Peixoto JR, et al. (2005). Potencial de Espécies Silvestres de Maracujazeiro como Fonte de Resistência a Doenças. In: Maracujá: Germoplasma e Melhoramento Genético (Braga MF, Faleiro FG, Peixoto JR and Bernacci LC, eds.). Embrapa Cerrados, Planaltina, 81-108.

Junqueira NTV, Lage DAC, Braga MF, Peixoto JR, et al. (2006). Reação a doenças e produtividade de um clone de maracujazeiro-azedo propagado por estaquia e enxertia em estacas herbáceas de Passiflora silvestre. Rev. Bras. Frutic. 28: 97-100.

Meletti LMM (2011). Avanços na cultura do maracujá no Brasil. Rev. Bras. Frutic. 33: 83-91.

Meletti LMM, Santos RR and Minami K (2000). Melhoramento do maracujazeiro-amarelo: obtenção do 'Composto IAC27'. Sci. Agric. 57: 491-498.

Mohammadi SA and Prasanna BM (2003). Analysis of genetic diversity in crop plants - salient statistical tools and considerations. Crop Sci. 43: 1235-1248.

Nascimento AVS, Santana EN, Braz ASK, Alfenas PF, et al. (2006). Cowpea aphid-borne mosaic virus (CABMV) is widespread in passionfruit in Brazil and causes passionfruit woodiness disease. Arch. Virol. 151: 1797-1809.

Negreiros JRS, Álvares VS, Bruckner CH, Morgado MAD, et al. (2007). Relação entre características físicas e o rendimento de polpa de maracujá-amarelo. Rev. Bras. Frutic. 29: 540-545.

Negreiros JRS, Araújo-Neto SE, Álvares VS, Lima VA, et al. (2008). Caracterização de frutos de progênies de meiosirmãos de maracujazeiro-amarelo em Rio Branco - Acre. Rev. Bras. Frutic. 30: 431-437.

Nunes TS and Queiroz LP (2006). Flora da Bahia: Passifloraceae. Sitientibus Ser. Cienc. Biol. 6: 194-226.

Padilla G, Cartea ME and Ordás A (2007). Comparison of several clustering methods in grouping kale landraces. $J . A m$. Soc. Hortic. Sci. 132: 387-395.

Pereira VM, Borges CV, Brandão LP, Oliveira LS, et al. (2012). Genetic diversity between improved banana diploids 
using canonical variables and the Ward-MLM method. Pesq. Agropec. Bras. 47: 1480-1488.

Pestana RK, Amorim EP, Ferreira CF, Amorim VB, et al. (2011). Genetic dissimilarity of putative gamma-ray-induced 'Preciosa-AAAB-Pome type' banana (Musa sp) mutants based on multivariate statistical analysis. Genet. Mol. Res. 10: 3976-3986.

Primot S, d'Eeckenbrugge GC, Rioux V, Pérez JAO, et al. (2005). Variación morfológica de tres especies de curubas (Passiflora tripartita var. mollissima, P. tarminiana y P. mixta) y sus híbridos en el Valle del Cauca (Colombia). Rev. Bras. Frutic. 22: 467-471.

SAS Institute (2000). Statistical Analysis System: User's Guide. SAS, Cary.

Santos CEM, Bruckner CH, Cruz CD, Siqueira DL, et al. (2009). Características físicas do maracujá-azedo em função do genótipo e massa do fruto. Rev. Bras. Frutic. 31: 1102-1110.

Santos EA, Souza MM, Abreu PP, Conceição LDHCS, et al. (2012). Confirmation and characterization of interspecific hybrids of Passiflora L. (Passifloraceae) for ornamental use. Euphytica 184: 389-399.

Silva MGM, Viana AP, Amaral Júnior AT, Gonçalves LSA, et al. (2012). Biometria aplicada ao melhoramento intrapopulacional do maracujazeiro-amarelo. Rev. Cienc. Agron. 43: 493-499.

Siqueira KMM, Kiill LHP, Martins CF, Lemos IB, et al. (2009). Ecologia da polinização do maracujá-amarelo, na região do Vale do Submédio São Francisco. Rev. Bras. Frutic. 31: 1-12.

Souza SAM, Martins KC, Azevedo AS and Pereira TNS (2012). Fenologia reprodutiva do maracujazeiro-azedo no município de Campos dos Goytacazes, RJ. Cienc. Rural 42: 1774-1780.

Sudré CP, Gonçalves LSA, Rodrigues R, Amaral Júnior AT, et al. (2010). Genetic variability in domesticated Capsicum spp. as assessed by morphological and agronomic data in mixed statistical analysis. Genet. Mol. Res. 9: 283-294.

Viana AP, Pereira TNS, Pereira MG, Souza MM, et al. (2003). Simple and canonic correlation between agronomical and fruit quality traits in yellow passion fruit (Passiflora edulis f. flavicarp) populations. Crop Breed. Appl. Biotechnol. 3: $133-140$.

Ward Junior JH (1963). Hierarchical grouping to optimize an objective function. J. Am. Stat. Assoc. 58: 236-244. 